\title{
Role of Bio-Fertilizer Treatments in Alleviating the Adverse Effect of Water Stress in Mangifera indica
}

\author{
R.R. Khalil ${ }^{*}$, Hoda A. Galal ${ }^{* *}$ and W.B. Darwisch ${ }^{* *}$ \\ *Department of Botany, Faculty of Science, Benha University, \\ Benha, and "Environmental Studies and Research Institute \\ (ESRI), University of Sadat City, Menofeia, Egypt.
}

\begin{abstract}
W ATER stress is one of the most important abiotic stresses that may limit agriculture production worldwide. This work was carried out on mango trees (Mangifera indica L.) to study the effect of exposure to different levels of drought stress $(65,75$, 85 and $100 \%$ of full irrigation requirements), in addition, to evaluating the role of using some plant growth promoting rhizobacteria (PGRP); such as Azospirillum and Azotobacter, in alleviating drought-induced changes. Physiological and biochemical changes were determined in mango leaves after two seasons of different treatments. Results indicated that membrane stability, photosynthetic pigments and insoluble sugar contents were significantly decreased with increasing drought levels, while electrolyte leakage, soluble sugars, total carbohy drates and proline content were sharply increased compared to control. Lipid peroxidation level and the activities of superoxide dismutase (SOD), peroxidase (POD) and catalase (CAT) enzymes showed progressive increases with drought levels. Application of biofertilizers may be effective in alleviating the adverse effect of water stress. Bio-fertilizers caused marked increase in photosynthetic pigments and carbohydrate contents and a decrease in proline content compared to control.
\end{abstract}

Keywords: Drought, Water stress, PGPR, Mangifera indica, Chlorophyll, Antioxidant enzymes, Proline.

\begin{abstract}
Abbreviations: PGRP, plant growth promoting rhizobacteria; ROS, reactive oxygen species; SOD, superoxide dismutase; POD, peroxidase; CAT, catalase; EL, Electroly te leakage; MSI, membrane stability index; DW, dry weight; FM, fresh mass; MDA, Malondialdehyde; S, Azospirillum; B, Azotobacter.
\end{abstract}

Countries in arid and semi-arid regions suffer from water shortage for agriculture usage. Water stress affects plant growth and productivity as it causes various physiological and biochemical changes including hormonal and nutritional imbalance, ion toxicity, desiccation, abscission, senescence and susceptibility to diseases (Nadeem et al., 2014). Also, drought can lead to pigment degradation (Hendry et al., 1987) causing irreversible damage to the photosynthetic apparatus (Clarke et al., 1996).

*Corresponding author: e-mail: radwan.aboelabbas @ fsc.bu.edu.eg. Tel: +201226264318, Fax: $+2013-3222578$ 
On the other hand, water stress can cause rapid damage to plant cells membrane due to an uncontrolled enhancement of reactive oxygen species (ROS) (Moussa and Abdel-Aziz, 2008). Excess accumulation of ROS may initiate destructive oxidative processes such as lipid peroxidation and chlorophyll bleaching as well as oxidation of proteins, deoxyribonucleic acid and carbohydrates (Ashraf, 2009). The degree of damage caused by ROS depends on the balance between the production of ROS and its removal by efficient antioxidant scavenging system which includes nonenzymic and enzymic antioxidants (Azooz et al., 2009). The enzymic antioxidants include superoxide dismutase (SOD), catalase (CAT), guaiacol peroxidase and enzymes of ascorbateglutahione (As A-GSH) cycle such as as corbate peroxidase, monodehydroascorbate reductase, dehydroascorbate reductase, and glutathione reductase (Sharma et al., 2012). Moreover, production and accumulation of proline is one of the most common adaptive strategies to cope with environmental stresses. Proline plays an important role in osmotic adjustment, detoxification of ROS and membrane integrity under stress conditions (Lisar et al., 2012).

Plant growth promoting rhizobacteria (PGPR) plays a significant role in enhancing plant growth and development under both stress and non-stress conditions (Nadeem et al., 2010; Kundu et al., 2011). They can improve plant tolerance towards abiotic stresses like drought, chilling injury, salinity, metal toxicity and high temperature (Grover et al., 2011). PGPR elicit physical and chemical changes that improve plant defense and enzymes activity; such as catalase and superoxide dismutase, which alleviate the oxidative damage induced by drought (Kohler et al., 2008 and Wang et al., 2012). Azospirillum and Azotobacter strains are non-symbiotic rhizobacteria. Azospirillum spp. can exert a positive effects on plant growth including synthesis of phyto-hormones, $\mathrm{N}_{2}$ fixation, nitrate reductase activity and enhancing minerals uptake (El-Komy et al., 2004). Moreover, Azospirillum spp. are associated with biochemical changes in roots, which in turn; promote plant growth and increase the tolerance to water stress (Ilyas et al., 2008). However, Azotobacter strains play a key role in harnessing the atmospheric nitrogen through its fixation in the roots and improve fertility condition of the soil (Mahato et al., 2009).

New reclaimed areas in Egypt, where the water sources are limited, are cultivated mainly with horticulture crops. Mango (Mangifera indica L.) is the second largest cultivated fruit in the tropical and subtropical regions in terms of cultivated area and quantity of production. In 2012, the mango cultivated areas in Egypt increased to more than 700,000 hectare (FAO, 2012). Irrigation of mango orchards; especially during the period of plant growth and fruit development, is vital to improve fruit size and quality, prevent fruit drop and sustainability of the orchard. Drought stress can cause a great reduction in the vegetative growth, flush length and weight, leaf water content and root growth of mango trees (Tahir et al., 2003).

Therefore, this investigation aimed to 1) assess the biochemical changes in Egypt. J. Bot., Vol. 56, No. 2 (2016) 
mango leaves; Owais cv., after two years of exposure to four levels of irrigation $(65,75,85$ and $100 \%$ of full irrigation requirements) and 2) evaluate the role of application of some non-symbiotic rhizobacteria such as Azospirillum and Azotobacter in alleviating drought-induced changes.

\section{Materials and Methods}

Our experiment was carried out in a private mango orchard placed at CairoAlexandria Desert Road. Eight to ten years old mango trees (cv. Owais); grafted onto seedling rootstock and planted at 5 meters apart in sandy soil under drip irrigation system, were selected for this study. Agricultural practices and chemical fertilizer were conducted as recommended by Egyptian Ministry of Agriculture and Land Reclamation (2004).

\section{Experimental design}

The experiment was laid out with sixteen treatments (three replicates for each) in randomized complete block design to study the interaction between four irrigation levels and four bio-fertilizer treatments. Four levels of irrigation (100, 85,75 and $65 \%$ of full water requirements) were applied in combinations with four bio-fertilizer treatments; $\mathrm{T}_{1}$ : Control (without using bio-fertilizer), $\mathrm{T}_{2}$ : Azospirillum, $\mathrm{T}_{3}$ : Azotobacter and $\mathrm{T}_{4}$ : Azospirillum + Azotobacter. Three rows of trees formed the border to the adjacent irrigation treatments.

\section{Irrigation treatments}

Water requirements for irrigation was calculated as potential crop evapotranspiration (ETc), based on climatic data obtained from the meteorological station of El-Tahrir, using CROPWAT computer program, which models crop-specific water requirement based on the Penman-Monteith equation (Allen et al., 1998).

$$
\mathrm{ET}_{\mathrm{C}}=\mathrm{k}_{\mathrm{C}} * \mathrm{ET}_{0}
$$

where, Kc: the crop coefficient which varies for different crops and their growth stages; $\mathrm{ET}_{0 \text { : }}$ the reference crop evapotranspiration (FAO, 1993).

The following irrigation treatments (Table 1) were applied starting February 2012 through the two successive growth seasons. Leaf samples were taken in April 2014.

TABLE 1. The amount of applied irrigation water based on crop water requirements.

\begin{tabular}{|l|c|}
\hline \multicolumn{1}{|c|}{ Irrigation treatments } & $\begin{array}{c}\text { Water quantity } \\
\left(\mathbf{m}^{\mathbf{3}} / \mathbf{f e d} \text { \%/year }\right)\end{array}$ \\
\hline 100\% of calculated water requirement (full irrigation) & 6545 \\
$85 \%$ of full irrigation requirement & 5564 \\
$75 \%$ of full irrigation requirement & 4909 \\
$65 \%$ of full irrigation requirement & 4255 \\
\hline
\end{tabular}


$*$ Fed $=4200 \mathrm{~m}^{2}$

Bio-fertilizer treatments

Two non-symbiotic rhizobacteria (Azospirilum lipoferum and Azotobacter chroccocum) were obtained from the microbiology department, Agriculture Research Center, Giza, Egypt. The two strains were grown on semisolid malate media (Dobereiner et al., 1976) and modified Ashby's (Abd El-Malak and Ishac, 1968), respectively. Strains were grown on liquid medium in a rotary shaker at $30^{\circ} \mathrm{C}$, then cultures were diluted and added to the trees at a rate of $500 \mathrm{ml} /$ tree $\left(10^{3}-10^{4}\right.$ cell. $\left.\mathrm{ml}^{-1}\right)$. Biofertilizers were mixed with the soil and covered at a depth of $30 \mathrm{~cm}$. in a ring one meter away from the trunk. Biofertilizer applications were repeated three times (February, March and April) in two seasons; 2012 and 2013.

\section{Laboratory analysis}

In May 2013, a bulk sample of 15-20 fully expanded leaves of mid-shoot was selected for each treatment. Leave samples were free from diseases, insects or mechanical damage. Fresh collected leaves were transferred directly in ice-box to the lab to estimate the following parameters.

\section{Electrolyte leakage}

The total inorganic ion leak from the leaves was measured by the method described by Sullivan and Ross (1979) in the form of electrolyte leakage. Twenty leaf discs of $2 \mathrm{ml}$ diameter were placed in a boiling tube containing $10 \mathrm{ml}$ double distilled water. The tubes were heated at $45^{\circ} \mathrm{C}\left(\mathrm{EC}_{\mathrm{a}}\right)$ and $55^{\circ} \mathrm{C}\left(\mathrm{EC}_{\mathrm{b}}\right)$ for $30 \mathrm{~min}$ in a water bath and the electrical conductivity (EC) was measured with a conductivity meter (ME977-C, Max Electronics, India). Subsequently, the tubes were boiled at $100^{\circ} \mathrm{C}$ for $10 \mathrm{~min}$ and the $\mathrm{EC}$ was again recorded $\left(\mathrm{EC}_{\mathrm{c}}\right)$. Electrolyte leakage was calculated with the following formula:

$$
\text { Electrolyte leakage }(\%)=(\mathrm{ECb}-\mathrm{ECa}) / \mathrm{ECc} \times 100
$$

\section{Membrane stability index}

The membrane stability index (MSI) was estimated in two sets, by placing $200 \mathrm{mg}$ of leaves in $10 \mathrm{ml}$ double distilled water in each set. First set was heated at $40^{\circ} \mathrm{C}$ for $30 \mathrm{~min}$ in a water bath and the second set was boiled at $100^{\circ} \mathrm{C}$ in a boiling water bath for $10 \mathrm{~min}$. Electrical conductivities $\left(\mathrm{C}_{1}\right.$ and $\left.\mathrm{C}_{2}\right)$ were measured, respectively using a conductivity meter (ME977-C, Max Electronics, India)..The MSI was calculated using the formula described by Premchandra et al. (1990) and modified by Sairam (1994): $\mathrm{MSI}=\left[1-\left(\mathrm{C}_{1} / \mathrm{C}_{2}\right)\right] \times 100$

\section{Photosynthetic pigments}

The contents of the photosynthetic pigments chlorophyll a (chl a), chlorophyll $b(\mathrm{chl} b)$ and carotenoids in fresh leaves were estimated using the spectrophotometric method described by Hassanein et al. (2009). The concentration of each pigment was calculated and expressed as $\mu \mathrm{g} . \mathrm{g}^{-1}$ dry weight (DW) of leaves. 


\section{Determination of carbohydrate content}

Soluble sugar was extracted from air -dried leaf tissue with $80 \%$ ethanol. One gram of the dried tissues was homogenized with $80 \%$ ethanol then put in a boiling water bath for $15 \mathrm{~min}$. After cooling, the extract was filtered and the filtrate was oven dried at $60^{\circ} \mathrm{C}$ then dissolved in a known volume of water to be ready for soluble sugars determination (Homme, et al., 1992). The soluble sugars were determined by the anthrone sulfuric acid method described by Scott and Melvin (1956). Polysaccharide content was determined in the dry residue left after extraction of soluble sugars. A known weight of dried material was added to $10 \mathrm{ml} 1.5 \mathrm{~N}$ sulphuric acid in sugar tube with air reflux and heated at $100^{\circ} \mathrm{C}$ in a water bath for $6 \mathrm{hr}$ (Hodge and Hofreiter, 1962). The hydrolysate was made up to a known volume to be ready for polysaccharide determination by the method of anthrone sulphuric acid reagent. Total carbohydrates content was calculated as the sum of the amounts of soluble sugars and polysaccharides in the same sample. All data were calculated as $\mathrm{mg} 100 \mathrm{~g}^{-1}$ DW of leaves.

\section{Estimation of proline content}

Free proline was extracted and determined in fresh leaves according to the procedure of Bates et al. (1973). Proline contents were determined and calculated as mg. $100 \mathrm{~g}^{-1} \mathrm{DW}$ of leaves.

\section{Protein content}

The total protein content in the leaves was estimated by adopting the methodology of Lowry et al. (1951). The protein was extracted with (0.1 M) $\mathrm{NaOH}$ and the Folin phenol reagent was added to develop the blue colour which was read at $600 \mathrm{~nm}$. A calibration curve was plotted by using bovine serum albumin to calculate the percentage protein content in the samples.

\section{Determination oflipid peroxidation}

The level of lipid peroxidation was measured in terms of malondialdehyde (MDA) contents using the method of Hodges et al. (1999).

\section{Antioxidative enzyme assay}

For the as say of antioxidant enzymes, the leaf tis sue $(0.5 \mathrm{~g})$ was homogenized in $50 \mathrm{mM}$ phosphate buffer $(\mathrm{pH} 7.0)$ containing $1 \%$ polyvinylpyrrolidone. The homogenate was centrifuged at $27,600 \times \mathrm{g}$ for $10 \mathrm{~min}$ at $4^{\circ} \mathrm{C}$, and the supernatant was used as source of the enzymes CAT (EC 1.11.1.6), POD (EC1.11.1.7) and superoxide dismutase (SOD; EC 1.15.1.1). For the estimation of peroxidase activity (Chance and Maehly, 1956), the enzyme extract $(0.1 \mathrm{ml})$ was added to the reaction mixture consisting of pyrogallol, phosphate buffer $\left(\mathrm{pH} \mathrm{6.8)}\right.$ and $1 \% \mathrm{H}_{2} \mathrm{O}_{2}$. The change in the absorbance was read every $20 \mathrm{~s}$ for $2 \mathrm{~min}$ at $420 \mathrm{~nm}$ on a spectrophotometer. A control set was prepared by adding DDW instead of enzyme extract. The reaction mixture for catalase consis ted of phos phate buffer ( $\mathrm{pH}$ 6.8), 0.1 $\mathrm{M} \mathrm{H}_{2} \mathrm{O}_{2}$ and enzyme extract $(1.0 \mathrm{ml}) . \mathrm{H}_{2} \mathrm{SO}_{4}$ was added to the reaction mixture, after incubating it for $1 \mathrm{~min}$ at $25^{\circ} \mathrm{C}$, and was titrated against potassium permanganate solution (Chance and Maehly, 1956). The activity of superoxide dismutase was

Egypt. J. Bot., Vol. 56, No. 2 (2016) 
as sayed by meas uring its ability to inhibit the photochemical reduction of nitroblue tetrazolium using the method of Beauchamp and Fridovich (1971). The reaction mixture containing $50 \mathrm{mM}$ phos phate buffer (pH 7.8), $13 \mathrm{mM}$ methionine, $75 \mathrm{mM}$ nitroblue tetrazolium, $2 \mathrm{mM}$ riboflavin, $0.1 \mathrm{mM}$ EDTA and 0-50 $\mu 1$ enzyme extract was placed under a 15-W fluorescent lamp. The reaction was started by switching on the light and was allowed to run for $10 \mathrm{~min}$. Fifty percent inhibition by light was considered as one enzyme unit.

\section{Statistical Analysis}

Mean values were analysed for differences using one-way ANOVA test. Duncan Multiple Range Test was used to determine significant difference between individual means, at the 0.05 level of significance. All the data were analyzed using SAS and MSTATC software.

\section{Results and Discussion}

\section{Electrolyte leakage and membrane stability index}

Membrane damage was evaluated indirectly by measuring solute leakage (electroly te leakage) fromcells and als o by MSI. The effect of different irrigation levels $(100,85,75$ and $65 \%$ of full irrigation) and Bio-fertilizer treatments on electrolyte leakage and membrane stability of mango leaves are demonstrated (Fig 1). Different levels of water stress caused a significant increase $(\mathrm{P}<0.05)$ in electrolyte leakage and decreased MSI of mango leaves compared to full irrigation treatment (100\%). Maximum membrane damage was recorded in the plants exposed to $65 \%$ of full irrigation. Water stress caused rapid damage to the plasma membrane due to an uncontrolled enhancement of free radicals that cause lipid peroxidation (Moussa and Abdel-Aziz, 2008). In addition, water stress caused disturbance of the as sociation between membrane lipids and proteins as well as disturbance in enzymes activity and transportation capacity of membranes (Lis ar et al., 2012).

Bio-fertilizer applications alleviate the adverse effects of water stress on the plasma membrane denoted by the significant decrease in the electrolyte leakage. These results are in line with Naghashzadeh (2014) who found that mycorrhizal biofertilizer application improved membrane stability in maize plant as a consequence of enhancing nutrient uptake, extension of the root system and water status of the plants.

\section{Changes in photosynthetic pigments content}

Photosynthetic pigments content (chl a, chl b, carotenoids and total pigments) estimated in mango leaves are shown in Fig 2. The contents of all photosynthetic pigments were gradually decreased with the increase of water stress compared with full irrigation treatment. The lowest values of chl a, chl b, carotenoids and total pigments were recorded at $65 \%$ of full irrigation. Decrease in chlorophyll content under water stress is expected since water stress inhibits chlorophyll (a \& b) synthesis along with their inclusion into developing pigment-protein complexes of the photosynthetic apparatus (Lisar et al., 2012).

Egypt. J. Bot., Vol. 56, No. 2 (2016) 
As regarding to the bio-fertilizer applications; the maximum values in all photosynthetic pigments were recorded with Azotobacter $\left(\mathrm{T}_{3}\right)$ under full irrigation (100\%), while Azospirillum $\left(\mathrm{T}_{2}\right)$ increased photosynthetic pigments under water stress treatments. The role of bio-fertilizers in increasing photosynthetic pigments may be due to higher $\mathrm{N}$ incorporation which contributed in the formation of chlorophyll (Baset Mia et al., 2010).

\section{Changes in carbohydrate contents}

Data illustrated in Fig 3. revealed that water stress induced significant increase in soluble sugars and total carbohydrates in mango leaves, as compared with those of full irrigation. Bio-fertilizer applications $\left(\mathrm{T}_{3}\right.$ and $\left.\mathrm{T}_{4}\right)$ stimulated the accumulation of soluble sugar and total carbohydrates in the stress-affected plants. On the other hand, the application of Azospirillum $\left(\mathrm{T}_{2}\right)$ led to significant decrease in soluble sugar and total carbohydrates, while the insoluble sugars increased, as compared with the control.
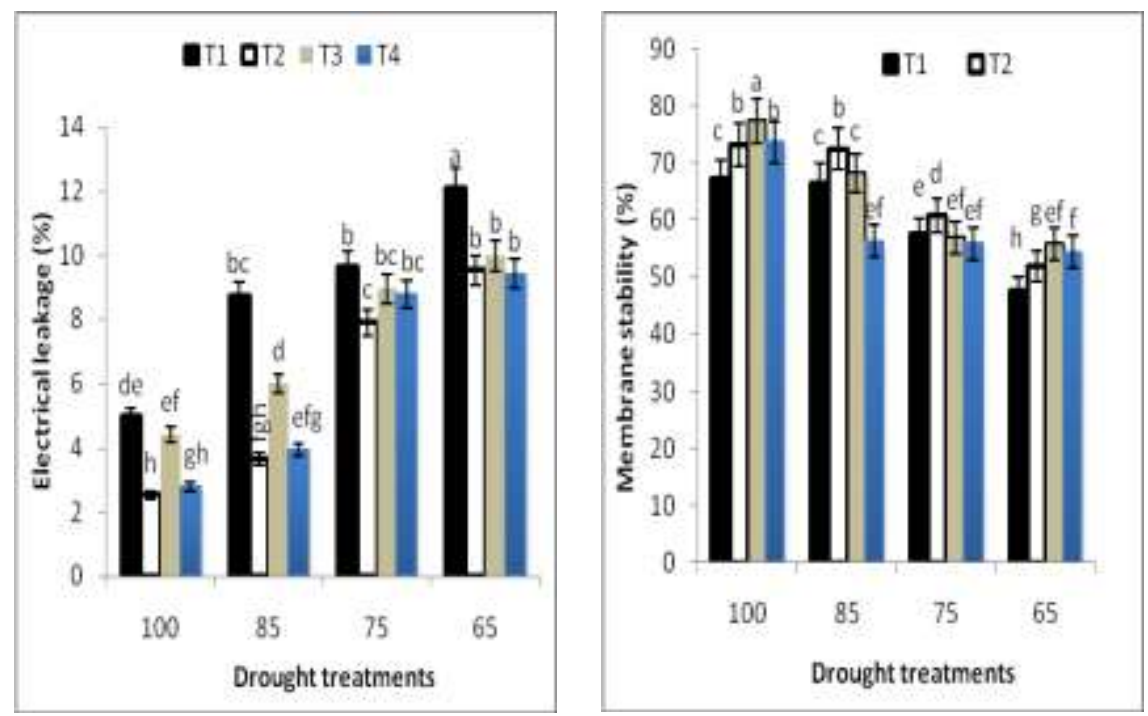

Fig 1. Effect of different irrigation levels $(100,85,75$ and $65 \%$ of full irrigation) and Bio-fertilizer treatments on electrolyte leakage (\%) and membrane stability (\%) of mango leaves.

where T1: control; T2: Azospirillum; T3: Azotobacter; T4: Azospirillum + Azotobacter; Error bars represent the standard deviation. 

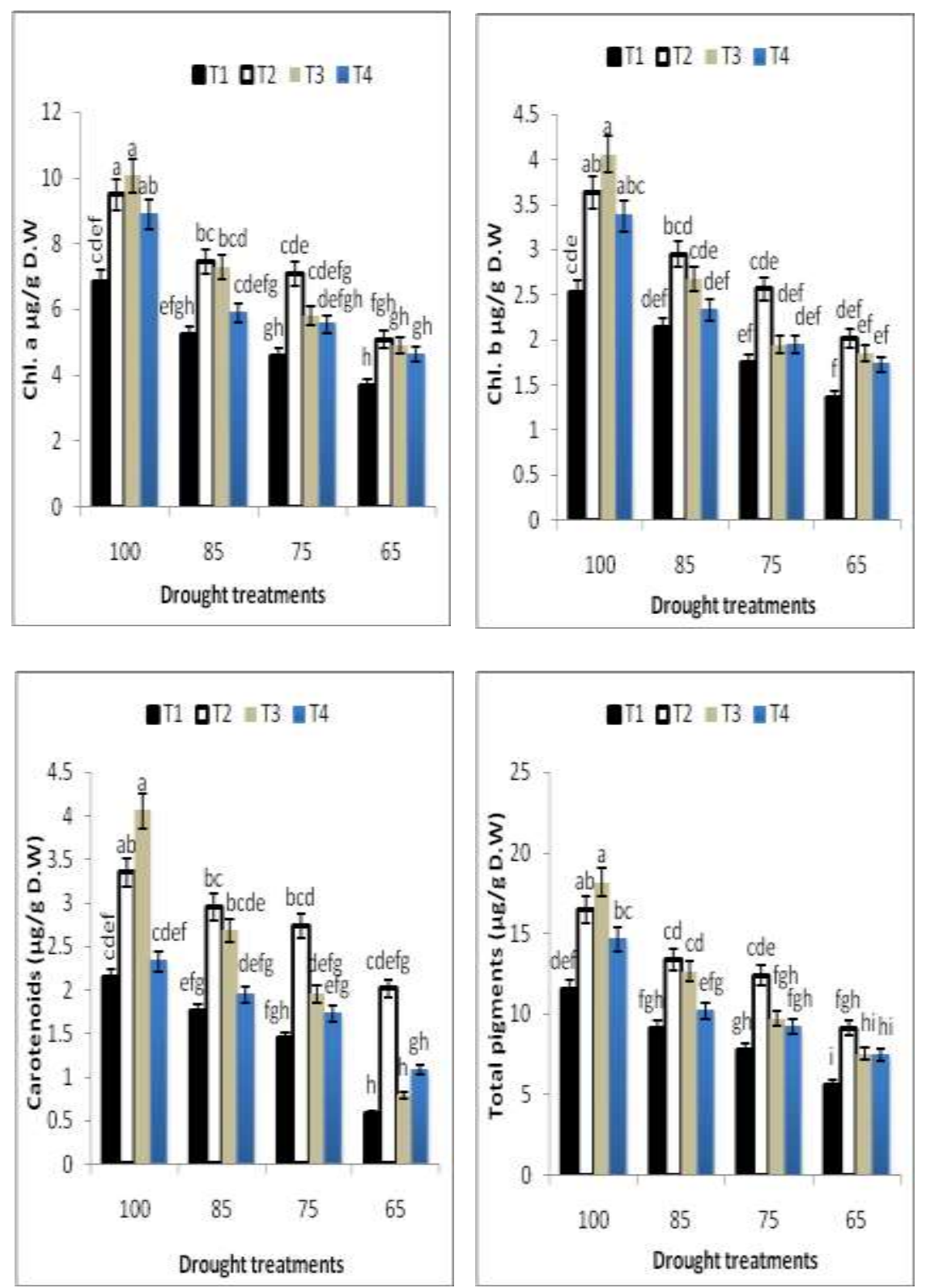

Fig 2. Effect of different irrigation levels $(100,85,75$ and $65 \%$ of full irrigation) and Biofertilizer treatments on Chl.a, Chl. b, carotenoids and total pigments in mango leaves.

Egypt. J. Bot., Vol. 56, No. 2 (2016) 
where T1: control; T2: Azospirillum; T3: Azotobacter; T4: Azospirillum + Azotobacter; Error bars represent the standard deviation.
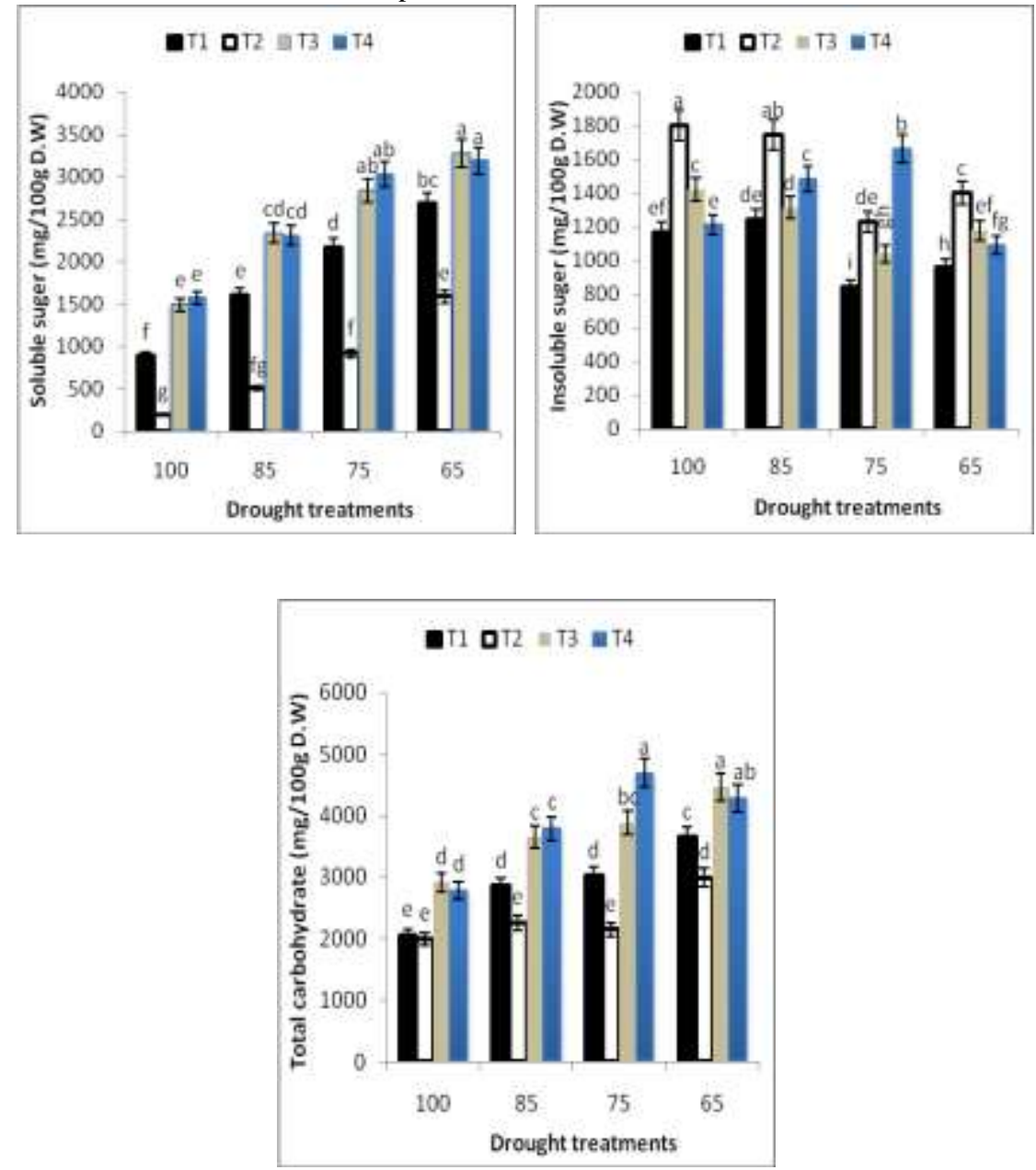

Fig 3. Effect of different irrigation levels $(100,85,75$ and $65 \%$ of full irrigation) and Bio-fertilizer treatments on soluble, insoluble sugar and total carbohydrates of mango leaves.

where T1: control; T2: Azospirillum; T3: Azotobacter; T4: Azospirillum + Azotobacter; Error bars represent the standard deviation.

\section{Changes in total protein and proline content}

The effects of different levels of irrigation and bio-fertilizer treatments on total protein and proline of mango leaves are presented (Fig 4). The decrease in total protein contents with increasing water stress may be due to proteolysis or decline in some essential minerals for protein synthesis, which are absorbed with water, as nitrogen compounds (Bayramov et al. 2010 and Costa et al. 2011). 
Furthermore, Lisar et al. (2012) reported that water stress alters gene expression and consequently, the synthes is of new proteins and mRNAs.

On contrast, water stress increased the proline content in mango leaves. This increase was directly proportional to water stress (Kim et al., 2004 and Lee et al., 2009). Proline accumulation in cells leads to increase in the osmotic potential and finally results in higher water uptake capacity by roots and water saving in the cells (Lis ar et al., 2012). On the other hand, proline acts as a source of carbon and nitrogen for rapid recovery from the stress and acts as a free radical scavenger and plasma membrane stabilizer (Hartzendorf and Rolletschek, 2001 and Lisar et al., 2012).

Bio-fertilizer treatments resulted in significant increase in the total protein contents in mango leaves, whereas it caused a significant reduction in proline content compared with those of the controls. The minimum proline content was recorded in Azospirillum treated plants $\left(\mathrm{T}_{2}\right)$ compared to other bio-fertilizer treatments. Our results were in agree with Abdelmoneim et al. (2014) who reported that protein content enhancement is related to a relative increases in nitrogen fixation due to PGPR application.

It was noticed that the increase in proline content in drought-stressed plants is associated with the decrease in chlorophyll content. This is consistent with the suggestion that nitrogen might be redirected to the synthes is of proline instead of chlorophyll (Da La Rosa-Ibarra and Maiti, 1995). These results demonstrated the efficiency of using bio-fertilizers; especially Azospirillum, in alleviating the adverse effect of water stress on mango.

\section{Lipid Peroxidation}

Data presented in Fig 5. showed the effect of different levels of irrigation and bio-fertilizer treatments on the lipid peroxidation as malondialdehyde in mango leaves. Water stress increased the MDA content significantly. This result is in constant with earlier studies which reported lipid peroxidation as a well-known effect of drought and many other environmental stresses via oxidative damage (Abdul Jaleel et al., 2008 and Lisar et al., 2012).

The application of bio-fertilizers led to significant decrease in MDA under low levels of irrigation (75 and 65\%) while, no significant differences were observed at (100 and $85 \%)$ of irrigation levels, except with $\mathrm{T}_{4}$ treatment under full irrigation. Bio-fertilizer treatments may improve the membrane stability through the decrease in lipid peroxidation. In this sense, low concentration of MDA has been associated with drought tolerance in tomato (Sanchez-Rodriguez et al., 2010) and maize (Moussa and Abdel-Aziz, 2008). Also, lower lipid peroxidation and higher membrane stability have been reported in salt-tolerant genotypes of rice (Tijen and Ismail, 2005) and sugarcane (Gomathi and Rakkiyapan, 2011).

Egypt. J. Bot., Vol. 56, No. 2 (2016) 

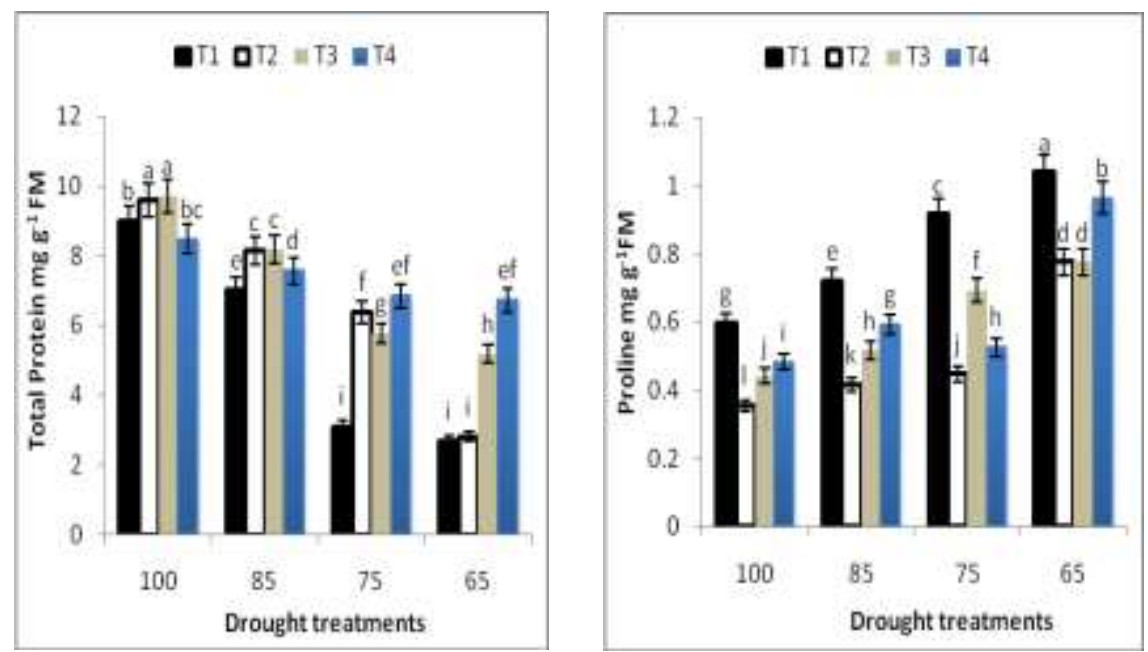

Fig 4. Effect of different irrigation levels $(100,85,75$ and $65 \%$ of full irrigation) and Bio-fertilizer treatments on total protein and proline in mango leaves.

where T1: control; T2: Azospirillum; T3: Azotobacter; T4: Azospirillum + Azotobacter; Error bars represent the standard deviation.

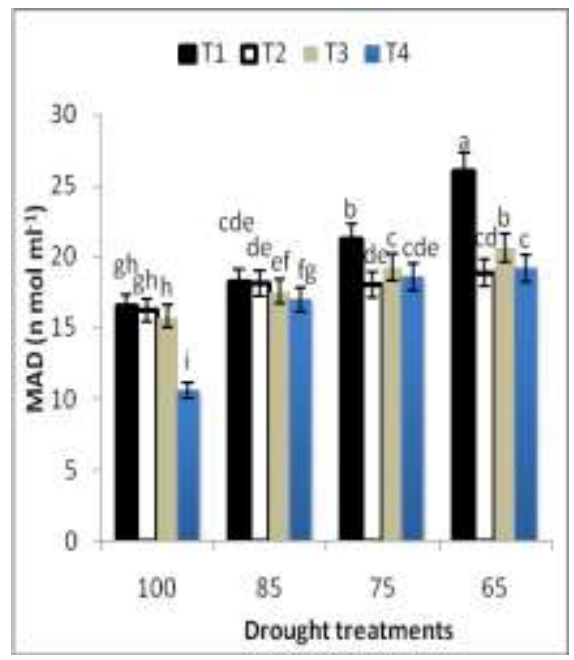

Fig 5. Effect of different irrigation levels $(100,85,75$ and $65 \%$ of full irrigation) and Bio-fertilizer treatments on lipid peroxidation as malondialdehyde (MDA) in mango leaves.

where T1: control; T2: Azospirillum; T3: Azotobacter; T4: Azospirillum + Azotobacter; Error bars represent the standard deviation. 


\section{Antioxidant enzyme activities}

Antioxidant enzymes are very important in scavenging dangerous free oxygen radicals, produced as the usual secondary consequence of environmental stresses, from plant cells. SOD converts the toxic $\mathrm{O}_{2}^{-}$radicals to $\mathrm{H}_{2} \mathrm{O}_{2}$ which scavenged to $\mathrm{O}_{2}$ and water by the antioxidant enzymes such as CAT and POD (Ozkur et al., 2009). The results illustrated in Fig 6. showed the effect of different levels of irrigation and bio-fertilizer treatments on the activity of the antioxidant enzymes (SOD, POD and CAT) in mango leaves. The activity of all antioxidant enzymes increased with increasing water stress. These results are in harmony with Moussa and Abdel-Aziz (2008) and Lisar et al. (2012) who reported that the increase in antioxidant enzymes (SOD, CAT and POD) activity under various stress conditions had been linked with cell protection from oxidative damage.

Application of bio-fertilizer treatments led to significant increase of SOD, POD and CAT activity which could alleviate the adverse effect of water stress on mango trees. The maximum activity of CAT recorded in plants treated with Azospirillum $\left(\mathrm{T}_{2}\right)$ at different levels of irrigation, compared with the other biofertilizer treatments. Similar results concerning antioxidant protective effects of PGPR associated with other environmental stresses where previously reported (Saravanakumar et al., 2011 and Heidari and Golpayegani, 2012). Moreover, earlier reports revealed that SOD activity increased in drought-tolerant cultivars of bean (Turkan et al., 2005), and sesame (Fazeli et al., 2007). Also, high activity of CAT is noticed with drought tolerance in tomato cultivars (SanchezRodriguez et al., 2010), and peanut (Akcay et al., 2010).

\section{Conclusion}

Under drought conditions plants adopt certain strategies to overcome the damage caused by water stress through enhanced production of antioxidant enzymes such as; SOD, POD, and CAT, organic solutes (soluble sugar and total carbohydrates) and also increased proline accumulation. Bio-fertilizer applications (Azospirillum and Azotobacter) could alleviate the adverse effects of water stress by increasing antioxidants activity, reduction of electrolytes leakage, accumulation of carbohydrate content, enhanced photosynthetic pigments, increased total protein contents, reduced proline content and MDA.

Recommendation: Bio-fertilizer applications, especially Azospirillum could be effective in mango orchards in arid and semi-arid areas to reduce the adverse effects of water shortage.

Egypt. J. Bot., Vol. 56, No. 2 (2016) 

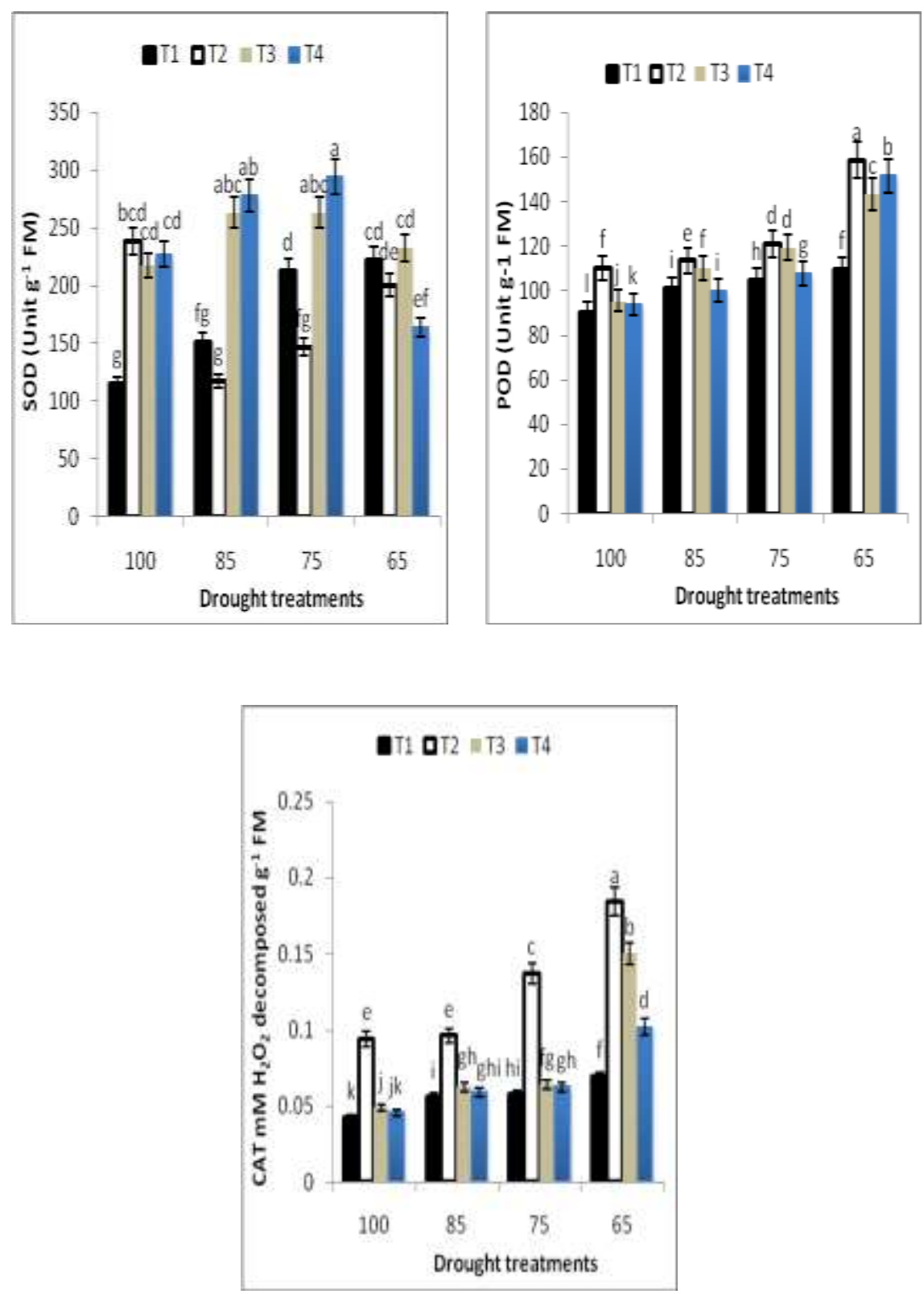

Fig 6. Effect of different irrigation levels $(100,85,75$ and $65 \%$ of full irrigation) and Bio-fertilizer treatments on SOD, POD and CAT in mango leaves.

where T1: control; T2: Azospirillum; T3: Azotobacter; T4: Azospirillum Azotobacter; Error bars represent the standard deviation. 
Acknowledgements: We thank the Faculty of Science, Benha University and ESRI, Sadat City Univ. for funding this study and for permitting us to carry out the experiment using their laboratory facilities. The authors would like to thank Dr. Mohamed Yusuf at AMU India for his comments that help improve the manuscript.

\section{References}

Abd El-Malak, Y. and Ishac, Y.Z. (1968) Evaluation methods used in counting Azotobacter. J. Appl. Bact., 331, 269-275.

Ahemad, M. and Kibret, M. (2014) Mechanisms and applications of plant growth promoting rhizobacteria: Current perspective. Journal of King Saud University Science, 26, 1-20.

Akcay, U.C., Ercan, O., Kavas, M., Yildiz, L., Oktem, H.A. and Yucel, M. (2010) Drought-induced oxidative damage and antioxidant responses in peanut (Arachishypogaea L.) seedlings. Plant Growth Regul., 61(1), 21-28.

Allen, R.G., Pereira, L.S., Raes, D. and Smith, M. (1998) Crop evapotranspiration guidelines for computing crop water requirement. Food Agric. Organ., Rome.

Ashraf, M. (2009) Biotechnological approach of improving plant salt tolerance using antioxidants as markers. Biotechnol. Adv., 27, 84-93.

Azooz, M.M., Ismail, A.M. and Elhamd, M.F. (2009) Growth, Lipid peroxidation and antioxidant enzyme activities as a selection criterion for salt tolerance of maize cultivars grown under salinity stress. Int. J. Agric. Biol., 11, 21-26.

Baset Mia, M.A., Shamsuddin, Z.H., Wahab, Z. and Marziah, M. (2010) Effect of plant growth promoting rhizobacterial (PGPR) inoculation on growth and nitrogen incorporation of tissue-cultured Musa plantlets under nitrogen-free hydroponics condition AJCS, 4(2), 85-90.

Bates, L.S., Wladren, R.P. and Tear, L.D. (1973) Rapid determination of free proline for water-stress studies. Plant Soil, 39: 205-207.

Bayramov, M.S., Babayen, G.H., Khaligzade, N.M., Guliyev, M.N. and Raines, A.C. (2010) Effect of water stress on protein pontent of some calvin cycle enzymes in different wheat genotypes. Proceedings of ANAS (Biological Sciences), 65(5):106111.

Abdelmoneim, T.S., Moussa, T.A.A., Almaghrabi, O.A., Alzahrani1, H.S. and Abdelbagi, I. (2014) Increasing plant tolerance to drought stress by inoculation with arbuscular my corrhizal fungi. Life. Sci. J., 11(1), 10-17

Abdul Jaleel, C., Sankar, B., Murali, P.V., Gomathinayagam, M., Lakshmanan, G.M.A. and Panneerselvam, R. (2008) Water deficit stress effects on reactive oxygen metabolism in Catharanthus roseus; Impacts on ajmalicine accumulation. Colloids Surf, 62(1), 105-111. 
Beauchamp, C.O. and Fridovich, I. (1971) Superoxide dismutase: improved assays and assay applicable to acry lamide gels. Analytical Biochemistry, 44, 276-287.

Chance, B. and Maehly, A.C. (1956) Assay of catalase and peroxidases. Methods in Enzymology, 2, 764-776.

Clarke, N.A., Hetschkun, H.M. and Thomas, T.H. (1996) Stress mechanisms in sugar beet. In: "The Roy al Society of Chemistry" Fenwick GR, Hedley C, Richards RL, and Khokhar $\mathrm{S}$ [Eds.], Agric food quality, an interdisciplinary approach 75-78, Cambridge.

Costa, D.L.C.R., Lobato, S.D.K.A., Silvera, D.G.A.J. and Laughinghousevi, D.H. (2011) ABA mediated proline synthesis in cowpea leaves exposed to water deficiency and rehydration. Turk. J. Agric. For., 35, 309-317.

Da La Rosa-Ibarra, M.M. and Maiti, R.I.K. (1995) Biochemical mechanism in glossy sorghum lines for resistance to salinity stress. J. Plant Physiol., 146, 515-519.

Dobereiner, I., Marrial, L.E. and Nery, M. (1976) Ecological distribution of Spirillum Lipoferum Bejierink. Canadian J. Microbial., 22: 1464-1473.

Egyptian Ministry of Agriculture and Land Reclamation (2004) Mango; cultivation and production. "Bulletin" No. 857.

El-Komy, H.M., Abdel-S amad, H.M., Hetta, A.M. and Barakat, N.A. (2004) Possible roles of nitrogen fixation and mineral uptake induced by rhizobacterial inoculation on salt tolerance of maize. Pol. J. Microbiol., 53(1):53-60.

FAO (1993) CLIMWAT for CROPWAT a climatic database for irrigation planting and management. "Irrigation and Drainage". Paper No. 49, Rome.

FAO (2012) Food and Agricultural Organization of the United Nations. http:// faostat 3. fao. org.

Fazeli, F., Ghorbanali, M. and Niknam, V. (2007) Effect of drought on biomass, protein content, lipid peroxidation and antioxidant enzymes in two sesame cultivars. Biol. Plantarum, 51: 98-103.

Gomathi, R. and Rakkiyapan, P. (2011) Comparative lipid peroxidation, leaf membrane thermostability, and antioxidant system in four sugarcane genotypes differing in salt tolerance. Inter. J. Plant Physiol. Biochem., 3(4): 67-74.

Grover, M., Ali, Sk.Z., Sandhya, V. and Venkateswarlu, B. (2011) Role of microorganisms in adaptation of agriculture crops to abiotic stresses. World $J$. Microbiol Biotechnol., 27, 1231-1240.

Hartzendorf, T. and Rolletschek, $\mathbf{H}$. (2001) Effect of $\mathrm{NaCl}$ salinity on amino acid and carbohydrate contents of Phragmites australis. Aquatic Botany, 69, 195-208.

Hassanein, R.A., Bassuony, F.M., Baraka, D.M. and Khalil, R.R. (2009) Phy siological effects of nicotinamide and ascorbic acid on Zea mays plant grown under salinity stress. I-Changes in growth, some relevant metabolic activities and oxidative defense systems. Res. J. Agr. Biol. Sci., 5: 72-81. 
Heidari, M. and Golpayegani, A. (2012) Effects of water stress and inoculation with plant growth promoting rhizobacteria (PGPR) on antioxidant status and photosynthetic pigments in basil (Ocimum basilicum L.). J. Saudi Socie. Agric. Sci., 11(1), 57-61.

Hendry, G., Houghton, J.D. and Brown, S.B. (1987) The degradation of chlorophyll a biological enigma. New Phytologist, 107: 255-302.

Hodge, J.E. and Hofreiter, B.T. (1962) Determination of reducing sugars and carbohy drates. In: "Methods in Carbohydrate Chemistry" Whistler RL, Walfrom ML (Eds). Academic Press, New York, London, pp 380-394.

Hodges, D.M., Delong, J.M., Forney, C. and Prange, P.K. (1999) Improving the thiobarbituric acid. Reactive substances assay for estimating lipid peroxidation in plant tissues containing anthocyanin and other interfering compound. Planta, 207:604-611.

Homme, P.M., Conalez, B. and Billard, J. (1992) Carbohydrate content, fructose and sucrose, enzyme activities in roots, stubble and leaves of rye grass (Lolium perenne L.) as affected by source/sink modification after cutting. J. Plant Physiol., 140: 282-291.

Ilyas, N., Bano, A. and Iqbal, S. (2008) Variation in Rhizobium and Azospirillum strains isolated from maize growing in arid and semiarid areas. Int. J. Agri. Biol., 10(6):612.618.

Kim, T.H., Lee, B.R., Jung, W.J., Kim, K.Y., Avice, J.C. and Qurry, A. (2004) De novo protein synthesis in relation to ammonia and proline accumulation in water stressed white clover. Funct. Plant. Biol., 31: 847-855.

Kundu, S., Datta, P., Mishra, J., Rashmi, K. and Ghosh, B. (2011) Influence of biofertilizer and inorganic fertilizer in pruned mango orchard cv. Amrapali. Journal of Crop and Weed, 7(2): 100-103.

Lee, B.R., Jin, Y.L., Avice, J.C., Cliquet, J.B., Qurry, A. and Kim, T.H. (2009) Increased proline loading to phloem and its effects on nitrogen uptake and assimilation in water-stressed white clover (Trifolium repens). New Phytol., 182: 654-663.

Lisar, S.Y.S., Motafakkerazad, R., Hossain, M.M. and Rahman, I.M. (2012) "Water Stress in Plants: Causes, Effects and Responses, Water Stress", Ismail Md. Mofizur Rahman (Ed.), ISBN: 978-953-307-963-9, In Tech, http:// www. intechopen. com/ books/ water-stress/ water-stress-inplants-causes-effects-and-responses.

Lowry, O.H., Rosenbrough, N.J., Aarr, A.L. and Randaal, R.J. (1951) Protein measurement with Folin phenol reagent. J. Biol. Chem., 193: 265-275.

Mahato, P., Anoop Badoni and Chauhan, J.S. (2009) Effect of Azotobacter and nitrogen on seed germination and early seedling growth in tomato. Researcher, 1(4): 62-66.

Moussa, H. and Abdel-Aziz, S.M. (2008) Comparative response of drought tolerant and drought sensitive maize genoty pes to water stress. Aust. J. Crop Sci., 1: 31-36.

Egypt. J. Bot., Vol. 56, No. 2 (2016) 
Nadeem, S.M., Ahmad, M., Zahir, Z.A., Javaid, A. and Ashraf, M. (2014) The role of mycorrhizae and plant growth promoting rhizobacteria (PGPR) in improving crop productivity under stressful environments. Biotech. Advances, 32: 429-448.

Naghashzadeh, M. (2014) Response of relative water content and cell membrane stability to my corrhizal biofertilizer in maize. E. J. Bio., 10(3):68-72.

Ozkur, O., Ozdemir, F., Bor, M. and Turkan, I. (2009) Phy siochemical and antioxidant responses of the perennial xerophyte Capparis ovata desf. to drought. Environ. Exper. Bot., 66: 487-492.

Premchandra, G.S., Saneoha, H. and Ogata, S. (1990) Cell membrane stability, an indicator of drought tolerance as affected by applied nitrogen in soybean. J. Agr. Sci. Camb., 115: 63-66.

Sairam, P.K. (1994) Effect of homobrassinolide application on plant metabolism and grain yield under irrigated and moisture stress condition of two wheat varieties. Plant Growth Regul., 14:173-181.

Sanchez-Rodriguez, E., Rubio-Wilhelmi, M., Cervilla, L.M., Blasco, B., Rios, J.J., Rosales, M.A., Romero, L. and Ruiz, J.M. (2010) Genotypic differences in some physiological parameters symptomatic for oxidative stress under moderate drought in tomato plants. Plant Sci., 178: 30-40.

Saravanakumar, D., Kavino, M., Raguchander, T., Subbian, P. and Samiyappan, R. (2011) Plant growth promoting bacteria enhance water stress resistance in green gram plants. Acta Physiologiae Plantarum, 33(1), 203-209.

Scott, T.A. and Melvin, E.H. (1956) Anthrone colorimetric method. In: "Methods in Carbohydrate Chemistry" Whistler RL, Walfrom ML (Ed.). Academic Press, New York.

Sharma, P., Jha, A.B., Dubey, R.S. and Pessarakli, M. (2012) Reactive oxy gen species, oxidative damage, and antioxidative defense mechanism in plants under stressful conditions. Journal Botany. http://dx.doi.org/10.1155/2012/217037.

Sullivan, C.Y. and Ross, W.M. (1979) Selection for drought and heat tolerance in grain sorghum. In: "Stress Physiology in Crop Plants", Hussel H. and Staples R. (Eds). Wiley Inteerscience, New York, pp 263-281.

Tahir, F.M., Ibrahim, M. and Hamid, K. (2003) Effect of Drought Stress on Vegetative and Reproductive Growth Behaviour of Mango (Mangifera indica L.). Asian Journal of Plant Sciences, 2: 116-118.

Tijen, D. and Ismail, T. (2005) Comparative lipid peroxidation, antioxidant defense systems and proline content in roots of two rice cultivars differing in salt tolerance. Environ. Exp. Bot., 53: 247-257.

Turkan, I., Bor, M., Ozdemir, F. and Koca, H. (2005) Differential responses of lipid peroxidation and antioxidants in the leaves of drought-tolerant $P$. acutifolius gray and drought-sensitive $P$. vulgaris $\mathrm{L}$. subjected to polyethylene glycol mediated water stress. Plant Sci., 168:223-231.

Egypt. J. Bot., Vol. 56, No. 2 (2016) 
Wang, C.J., Yang, W., Wang, C., Gu, C., Niu, D.D., Liu, H.X., Wang, Y.P and Guo, J.H. (2012) Induction of drought tolerance in cucumber plants by a consortium of three plant growth-promoting rhizobacterium strains. PLOS ONE 7(12): e52565.

(Received 4/10/2015; accepted 21/2/2016)

\title{
دورالمعاملة بالسماد الحيوى في الحد من الآثار السلبية للإجهاد

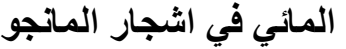

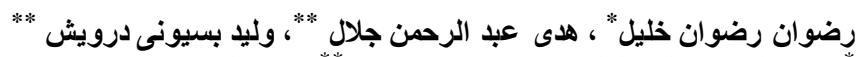

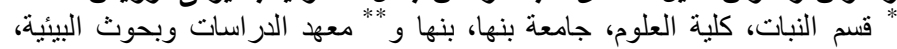

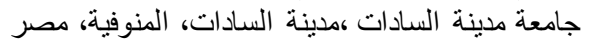

\begin{abstract}
يعد الجفاف واحد من اهم الاجهادات غير الحيوية التى تحد من الإنتاج الزر اعي في التي التي التئي

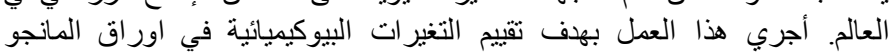
(Mangifera indica L)

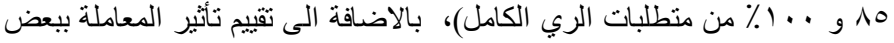

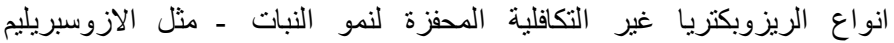

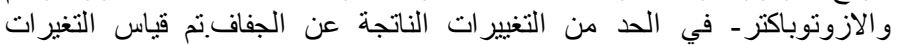

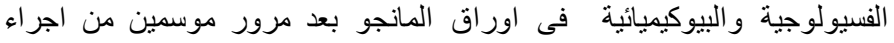

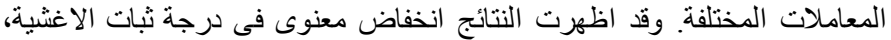

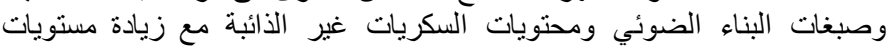

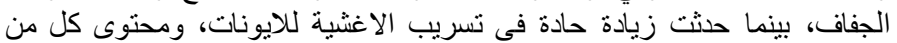

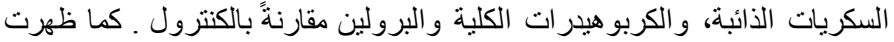

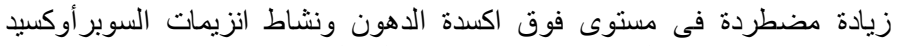

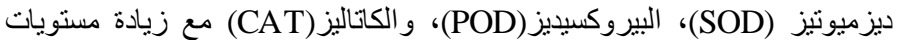

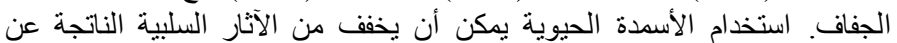

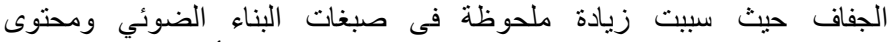

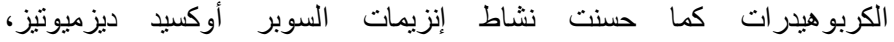
البيروكسيديز، و الكاتاليز، وكذللك خفضت محتوى البرولين فى النباتات المعاملة مقارنةً بالكنترول.
\end{abstract}

